Article

\title{
Constructing questions for the social professions of today: the case of social pedagogy
}

\author{
Xavier Úcar (1) \\ Professor of Social Pedagogy, Department of Educational Theories and Social Pedagogy, Autonomous \\ University of Barcelona, Spain; xavier.ucar@uab.cat
}

How to Cite: Úcar, X. (2021). Constructing questions for the social professions of today: the case of social pedagogy. International Journal of Social Pedagogy, 10(1): 9.

DOI: https://doi.org/10.14324/111.444.ijsp.2021.v10.x.009.

Submission date: 2 April 2020; Acceptance date: 6 July 2021; Publication date: 18 August 2021

\section{Peer review:}

This article has been peer-reviewed through the journal's standard double-blind peer review, where both the reviewers and authors are anonymised during review.

\section{Copyright:}

(C) 2021, Xavier Úcar. This is an open-access article distributed under the terms of the Creative Commons Attribution License (CC BY) 4.0 https://creativecommons.org/licenses/by/4.0/, which permits unrestricted use, distribution and reproduction in any medium, provided the original author and source are credited • DOI: https://doi.org/10.14324/111.444.ijsp.2021.v10.x.009.

\section{Open access:}

International Journal of Social Pedagogy is a peer-reviewed open-access journal.

\begin{abstract}
The complex societies we now inhabit oblige us to question, reformulate or even rupture the traditional socio-political frameworks in which social pedagogy and the social professions have been developed and in which the theories that explain and justify them have been constructed. These frameworks have institutionalised concepts, practices and methodologies that often no longer fit within the complexity of today's constantly changing realities. The aim of this article is to propose and analyse some key foundations for understanding the social professions and the actions they carry out. It concerns itself with generating questions that link social pedagogy and the social professions with the complexity of today's social life. The questions address the current content of what we refer to as 'the social' and its relationship with other dimensions such as politics, culture and the environment. Among other issues, the article addresses how the social professions have developed within the political framework of the welfare state. Based on the answers to these questions, we argue in favour of updating the term 'social' with renewed connotations, and of defining the 'good life' as the reference point that must give it meaning.
\end{abstract}


Keywords social pedagogy; social professions; social work; welfare state; neoliberalism; social policy; 'the social'; Buen vivir; 'the good life'

We live in a world where the prevailing rule seems to be that the more essential our occupation is (cleaning, caring, teaching), the less it is valued in terms of GDP.

(Bregman, 2017, p. 103)

\section{Introduction}

As we understand it today, social pedagogy leads us to question the idea, inherited from late industrial society, that only formal education provides the learning content necessary for people to access the world of work and be integrated in society in what might be referred to as a normal way. And that all people who, for whatever reasons, cannot adequately follow this pathway have to be treated, helped or institutionalised, regardless of their own opinions or wishes.

Despite such questions, current political discourses reveal how nation states continue to cling to these life formulas that seem increasingly outdated today. ${ }^{1}$ States that are being overwhelmed by abundant, diverse and heterogeneous flows of ideas, people, events, situations, capital and goods constantly crossing them and pressurising them from within and without. Among other causes, these flows derive from globalisation processes, situations of extreme poverty, armed conflicts between countries, ethnic groups or cultures and the massive displacement of refugees due to famine or war. They are also the result of the increasingly scandalous inequality between north and south, between the world's centre and its periphery. It is an inequality that has in recent decades also begun to establish itself in what was previously considered the centre and north of our planet; that is, at the heart of the most developed societies.

It seems that the complex societies we inhabit require the questioning, reformulating or in many cases rupturing of the traditional socio-political frameworks in which social pedagogy and social work have been developed and in which the theories that explain and justify them have been constructed. These closed, and often internationally isolated, frameworks have institutionalised concepts, practices and methodologies that often fail to fit with the complexity of today's continuously changing socio-cultural, political and environmental realities.

Social pedagogy is considered to be one of the social professions (Banks, 1999; Cleary, 2019; Lorenz, 2008; Sáez and Sánchez, 2006; Úcar, 2016b). But neither these professions nor the welfare state, which initially supported them and in which they proliferated, have been spared from crises. The former as a consequence of what Dubet (2006) characterised as the 'decline of the institutional [socialisation] programme' (p. 18) or, in other words, the loss of the halo of transcendence that had traditionally legitimised and shielded them from any type of questioning. ${ }^{2}$ And the latter due to pressures generated by, among other factors, globalisation processes, demographic changes and the different economic and financial crises of recent decades.

Neither the society nor the social and cultural context in which social pedagogy and the social professions originated have much in common with what is happening in today's societies. The very idea of society has been in crisis for years (Touraine, 2013) and there are those who maintain that it makes more sense to speak of societies in the plural than in the singular (Dubet, 2013). The understanding of what constituted 'social' that established certain parameters of pedagogical action 170 years ago is very different to the consideration of 'social' that dictates pedagogical norms in our world today. And the same can be said in relation to social work.

Social pedagogy is about accompanying people in their daily life processes in the socio-cultural and environmental settings in which these take place. A process of help and accompaniment aimed at equipping people with the learning resources necessary to live their lives in a dignified and harmonious way in their territorial and community environments. In its purest essence, one of social pedagogy's most characteristic traits is that it is a pedagogy of everyday life. Today, however, everyday life involves a very heterogeneous and diverse multiplicity of exchanges and relationships on both physical and digital levels, which are in all cases socio-cultural, as well as being determined by political and environmental frameworks. 
Discussing social pedagogy today entails, first of all, trying to reconstruct the social, cultural, political and ecological frameworks in which it operates from an updated perspective. I believe that as social pedagogy theorists and professionals we have a moral obligation to evolve in parallel with these changes.

The aim of this article is to present and analyse some of what, from my point of view, are the key foundations for understanding the social professions today. The idea is not to provide a state-of-the-art review or even an analysis of how the concept of 'social' has evolved in the social sciences (see Curtis, 2002), but to determine how this has been and how it may currently be understood within the framework of social pedagogy in order to offer an appropriate response to the complexity of social life today. I will do this by posing a series of questions that link social pedagogy, and the social professions in general, to the complexity of what it means to live in today's communities and societies.

The first section offers a discussion of the meaning and content of the term 'social', which qualifies both pedagogy and the so-called social professions. The second section analyses the evolution of the welfare state alongside that of the social professions. The article finishes with some conclusions that include the main answers obtained to the questions posed and some reflections on the possibility of achieving that possible better world to which many authors refer.

\section{What sense and meaning can be attributed to the term 'social' in the field of social pedagogy and the social professions?}

'Social' has always been our reference point in association with pedagogy and education, but also in relation to the terms 'care' or 'work'. It is a word and a concept that we have traditionally accepted as a given, stable and finished entity. Over the years it has become laden with meaning and, within the framework of the analytical paradigm that has prevailed since the nineteenth century (Sloterdijk, 2016), it has been treated as something specific and separate from other dimensions in the sphere of human activity.

It is a term that, in the field of social action, has at times referred to physical contexts, and at other times to relational contexts and networks of people, groups and communities. But in the vast majority of cases, it has been used to designate problematic situations where people are exposed to risk, vulnerability or need. It is particularly in relation to this last meaning that the social professions and especially social pedagogy have been constructed. This is a meaning that today remains predominant in most of the countries where social pedagogy has been developed (Janer and Úcar, 2019a, 2019b).

\section{What senses and meanings can be attributed to 'the social'?}

Since the nineteenth century, the term 'social' has been used to identify a whole series of sciences, methodologies, practices and professions that have a certain 'family air', to use Wittgenstein's well-known expression. All of these are, in one way or another, related to aspects or dimensions of life that people share in common, whether in groups, communities or societies. However, Swedberg (2016) stated that 'what constitutes "the social" is by no means agreed on in the social sciences ... That was as true a hundred years ago as it still is today' (p. 161).

Reflecting on the characteristics of the human condition, Arendt (2002) explained the original meaning of the word 'social', pointing out that the Romans were the first to give it meaning. The Greeks did not consider it to be a specifically human attribute, given that it is a trait that humans share with animals. Arendt (2002) explained that Seneca translated Aristotle's Zoon politikon as Animal socialis and that St Thomas Aquinas perpetuated this model of translation by saying 'home est naturaliter politicus, id est, socialis' (p. 38; see also Úcar, 2013, 2016a). ${ }^{3}$ This initial comparison between the social and the political has always generated (and still generates) much confusion, misunderstanding and different stances, both in the field of social pedagogy and in that of the social professions in general. We will deal with it specifically later.

The use of the concept 'the social' as we understand it today is very recent. Rendueles (2013) claimed that it became commonly used during the early phases of capitalism to designate the type of relationships that began to be established when the ancient communities that gave meaning to common life began to disappear. However, the idea that interests me most is that, according to Manuel (2010), 'the social' is a historical and contingent idea. In other words, it does not make sense to develop a closed, 
timeless and finished concept of it, but rather in all cases it must be awarded meaning in the space-time context to which it refers.

\section{What does the 'social' in social pedagogy refer to?}

Numerous authors have questioned the meaning of the word 'social' in social pedagogy (Caride, 2004; Cleary, 2019; Coussée, Bradt, Roose and Bouverne-De Bie, 2010; Hämäläinen, 2003a, 2012). Its use is not random since, as an essential reference for theory and practice, the term marks and delimits pedagogy's context for action, the characteristics of the activities it carries out, the values it conveys and, above all, the objectives it aims to achieve. This is precisely the reason why social pedagogy is normative (Cleary, 2019; Eriksson and Markström, 2003; Hämäläinen, 2003a; Petrie and Cameron, 2009): because it proposes norms, objectives, principles, techniques and methodologies for socio-educational action based on and oriented towards certain values. What comprises, then, this 'social' by means of which social pedagogy aims to form and accompany individuals, groups and communities?

It should be noted that in the specific field of social or socio-educational intervention the concept of 'the social' has historically been viewed as a stigma (Carballeda, 2002). If one reviews the trajectory of social pedagogy in practice since its inception as a theory more than a century and a half ago, for most of its history it has worked in problematic socio-cultural fields, whether due to the existence of deficits, conflicts or some kind of risk or vulnerability. In the field of pedagogy, throughout its history 'the social' has carried the stigma of being different or abnormal; this is probably because it was always linked with 'different' people; those who for whatever reason did not follow or could not follow those life-paths considered 'normal'. It concerned people whose personal, social and cultural differences could give rise to very plural and diverse situations: poverty, disability, marginalisation, maladaptation, social exclusion and so on.

Perhaps this can be explained, in terms of a general positioning of 'the social', by Rousseau's great influence on social and pedagogical thought. His influence lent negative connotations to the concept 'social' and oriented educational work in a very specific direction. Such connotations are likely very much related to how social philosophy has viewed the meaning of 'social' as a concept. Analysing how it has been developed by different authors since Rousseau, Honneth (2011) stated that 'the social' has always been treated negatively: 'Social philosophy is by no means a positive theory ... It is always a critique of a social state, which is perceived as alienated or meaningless, as objectified or even ill' (p. 114). Sloterdijk (2014) further explained this idea by pointing out that 'Rousseau detheologizes evil and transposes the source of corruption into the social field' (p. 27). It is therefore not so strange that the general concept of 'social', although more specifically in the pedagogical literature, has always been related to some kind of stigma, be it in the form of need, deficit, risk or problematic.

Having focused on this interpretation of 'the social', the field of practice social pedagogy ${ }^{4}$ may be understood as a pedagogy that deals exclusively with people in need or situations of risk, personal deficits and social problems. Generally speaking, this is the case in many countries, including, though not limited to, Spain, Denmark, the Czech Republic or Lithuania in Europe, and Brazil, Argentina and Mexico in Latin America (Janer and Úcar, 2019b). This is a social pedagogy that works from a compensatory or corrective approach (Lorenzova, 2017), and also one whose main mission is established as providing a response to social problems (Coussée et al., 2010; Hämäläinen, 2003b; Kraav, 2003; Smith and Whyte, 2007).

Since the mid-twentieth century, this understanding of what constitutes pedagogy and 'the social' has shifted in Europe, probably due, among other factors, to the growing importance that politics has begun to award to culture. ${ }^{5}$ Social pedagogy has also gradually begun to address normal situations in daily life, maintaining well-being (Eriksson and Markström, 2003) and, in particular, socio-cultural promotion and development for individuals, groups and communities. A good example of this is represented by the processes for promoting socio-cultural activities in communities and socio-educational work through culture and the arts in general.

Today, a perspective that exclusively links social pedagogy with individuals' and communities' deficits and problems is wholly insufficient, and it is important to note that this is currently changing in many countries. It is much more appropriate to argue that social pedagogy works with people who live their lives in highly complex spheres and deals with both the normal problems and situations that result from such complexity. Following Schugurensky and Silver (2013) and Hämäläinen (2012), in recent years social pedagogy can be said to have begun to position itself more in the sphere of community and 
human development, and not so much in terms of social needs and care. This is why Storø (2013) has argued that today, practical social pedagogy seeks to build rather than to compensate.

Without a clear and more or less consensual definition of what is meant by 'the social' within the framework of a society, it would appear difficult for the values it defends and the profesional training that it offers to meaningfully guide professionals' actions. The ideological appropriation of social pedagogy by the Nazi regime with the aim of instrumentalising it to impose its own values on German society (Kornbeck, 2013; Lorenz, 2008) is a good example of the risks inherent in what can happen when a concrete society does not or cannot have a dialogical or consensual definition of what comprises 'the social'.

\section{Is it possible or does it make sense to differentiate 'the social' from 'the political'?}

As we have already pointed out, given Thomas Aquinas's translation, it is not easy to distinguish the social from the political. Stances on the issue range along a polarised continuum from complete differentiation to total equality between the two. The former would correspond to strictly positivist epistemological stances, which ignore the context of phenomena, while the latter coincides with the more critical approaches, in which everything is political.

Many of the positions expressed by theorists and practitioners of social pedagogy and the social professions in general would be found between these two extremes. Cleary (2019) pointed out that 'the "social" represents the socio-political context that informs a given social pedagogical practice' (p. 2). In the first instance, it is in effect the political framework that marks the limits and possibilities of action for 'social' professionals.

Perhaps it is in the operative concept of 'social policy' where the relationship between what constitutes the social and the political can be seen more clearly. Social policy is understood as 'government policies designed to address a range of human needs, such as housing, education, subsistence and health' (Green and Clarke, 2016, p. 3). However, the content of said concept clearly does not escape the negative connotations of 'the social' alluded to previously.

\section{Is there life for the social professions beyond the welfare state?}

The welfare state is the political framework that, since the 1930s in particular, has defined the possibilities and characteristics of actions undertaken by the social professions. It refers to public sector intervention, via different mechanisms and regulations, to respond to the different types of needs and risks faced by a country's population (Muñoz de Bustillo Llorente, 2019). It is a political framework that, generally speaking, aims to improve the living conditions of citizens through its redistributive capacity (Benassi, 2010; Goul Andersen, 2012) and protect the more disadvantaged, or those living in poor social conditions.

The establishing of the welfare state in Europe provided fertile ground for the social professions to legitimise themselves and expand both their functions and specific areas of intervention. Most of what we know as 'the social professions' (Banks, 2004; Kornbeck, 2009; Lorenz, 2008) found their own place, recognised to a greater or lesser extent, in social life in the second half of the twentieth century and within the framework of the welfare state. This political framework represented a turning point in their identity, since it enabled them to 'be integrated within its services, benefits, norms and, finally, organizations' (García Roca, 2004, p. 50). The fundamental role of the social professions within the framework of welfare states has been to mediate between the system and the citizenry (Sáez and Sánchez, 2006); between the resources that the state can offer and the conditions, in the form of needs and risks, that vulnerable people and groups may display (Rosanvallon, 1995).

In the previous paragraph we referred to the welfare state in the plural. This is not the place to discuss existing types of welfare state; suffice it to say that, like 'the social', the political is embodied in different ways in different socio-cultural (national or international) contexts. Therefore, it makes perfect sense that the so-called social professions are also different in each country (Banks, 1999; Kornbeck, 2009).

In the welfare state, the 'social professions' have also been called welfare professions (Cleary, 2019); social welfare professions (Healy, 2009) and social and caring welfare professions (Blom, Everston 
and Perlinski, 2017). The term in fact refers to a whole series of professions focused on interpersonal relationships (Healy, 2009) and deeply involved in the well-being (Graham, 2011), health and education of people (Cleary, 2019). Although different authors may place greater emphasis on one social occupation and profession or another, generally speaking this term can include: social assistants, social pedagogues, social educators, youth workers, community workers, care workers, social advisors (Green and Clarke, 2016), special educators, child welfare nurses, welfare nurses, cultural animators, health professionals (Banks, 1999; Healy, 2009), elderly care workers, family assistants, psychologists and psychiatrists (Blom et al., 2017).

These 'social' occupations or professions have been dependent on the social policies of each state (Blom et al., 2017; Ferrera, 2008) and on the ideologies that have inspired them (Green and Clarke, 2016), emphasising the political nature of 'the social'. It is this close connection between the social and the political that has led the social professions to evolve and change in parallel with the transformations carried out in welfare states.

The arrival of the neoliberal model of politics in the 1970s brought with it a period of crisis and transformations for the welfare states (Dundar Aravacik, 2018; Ferrera, 2008; Green and Clarke, 2016; Hartman, 2005; Muñoz de Bustillo Llorente, 2019), and this continues today (Dundar Aravacik, 2018). It is a crisis that has been accentuated by the effects of globalisation and our entry into the age of information and communication technologies since the 1990s (Dundar Aravacik, 2018; Jayasuriya, 2004), and one that, as a result of economic cuts in social policies, has significantly affected the limits and very characteristics of the actions undertaken by the social professions, which have undergone considerable changes in Europe over the last three decades (Blom, Everston and Perlinski, 2017; Ferrera, 2008; Sáez and Sánchez, 2006).

Healy (2009) pointed out that the social welfare professions are suffering the 'corrosive effects' (p. 401) of what has been characterised as New Public Management or, in other words, the 'marketisation of welfare' (Green and Clarke, 2016, p. 123). This has involved, among many other factors, the decentralising of services, which can now be provided by the private or the third sector; the introduction of criteria aimed at economic maximisation; job flexibility and hiring; the prioritisation of quantitative and short-term results, service efficiency and effectiveness and, in general, management criteria more typical of the private than the public sector.

All of this has had very significant effects on the social professions and on social action itself, given that it has not only involved the privatisation of numerous welfare activities but also an increase in quantitative measures to monitor the work done by professionals, a standardisation and protocolisation of social intervention processes, the development of evidence-based practices rather than those based on professional judgment (Banks, 2004), a "'what works well" mentality' (Lorenz, 2017, p. 2) and, in general, 'a development towards standardized and ready-made welfare measures that threaten to transform welfare work into a robot-like distanced way of delivering standardized service to citizens' (Bruhn, 2019, p. 199). This is the reason for there being talk of a serious danger to social work, an erosion of the humanistic ethics of the social professions (Smirnova and Poluektova, 2019) and a loss or disappearance of spaces for professional deliberation due to the political demand for scientific knowledge and evidence-based practice' (Cleary, 2019, p. 5).

All of the above-mentioned effects have led to a proliferation of administrative regulations that have only increased bureaucracy for social professionals (Lorenz, 2017), but without this resulting in a perceptible improvement in either their training or the results of their actions on the participating people and communities. In fact, it has been pointed out that neoliberal approaches have exacerbated social inequality (Hartman, 2005; Trappenburg, Kampen and Tonkens, 2019).

And that is not all, since these regulations have also contributed to fragmenting and opposing the very actions undertaken by the social professions (Blom et al., 2017). As I have noted elsewhere, one of the many reasons for these confrontations between social professionals is the need to compete for spaces, jobs and services that the government offers to the highest bidder (Úcar, 2011). Perhaps, as Carballeda (2002) noted, it can be said that 'the predominance of cost-benefit considerations in the field of politics often transforms social action as a mode of intervention into a petty instrument, generating more social fragmentation than integration through practices of submission' (p. 71).

It is clear that these approaches bring the social professions and their mediating functions between the government and the public into question (Sáez and Sánchez, 2006), as well as their own autonomy in terms of operation. Equally, they also shed light on the question of who should be responsible for welfare, the state or society itself via coordination between the many groups, institutions and entities 
that comprise it (Hamlin, 2007). This is what has been referred to as the 'relational State' (Jayasuriya, 2004; Mendoza and Vernis, 2008), which is aimed at creating the so-called welfare society.

In line with this approach, some authors are referring to the emergence of a new model of welfare state called the neo-social state. 'It is, of course, an open question whether the neo-social state model will indeed be able to establish a radically new relationship between work and non-work, so as to guarantee that the domain of free time for play, intellectual and aesthetic contemplation, and intimacy is, once again, an autonomous realm free from commodification' (Carreira da Silva, 2017, p. 954).

Despite the numerous criticisms the welfare state has received over the years, and the cuts imposed by neoliberalism in relation to the state's commitments to provide protection, security, justice and infrastructure 'showing a high level of resilience' (Muñoz de Bustillo Llorente, 2019, p. 7), it still continues to regulate and implement social policies today and appears set to continue to do so in the future (Dundar Aravacik, 2018; Muñoz de Bustillo Llorente, 2019).

\section{Are social pedagogy and the social professions political? Can the actions they involve be considered politics?}

At the beginning of this section, I pointed out the polarised continuum along which authors addressing the social professions have positioned themselves. The interdependence between social policies, embodied in current legislation, and the actions undertaken by the social professions is a clear one, as we have seen in the previous section. It is a fact that the former frame and delimit the actions of the latter, as they are able to call into question the autonomy supposedly enjoyed by the latter - regardless of whether these professions operate within the framework of public administrations, in the private sphere or in the third sector.

What, then, is the role the social professions can or should play in the current political arena? In the specific case of social work, Feldman (2019) states that, despite the fact that there have been periodic attempts to engage in political action to generate social change throughout its history, in recent decades the profession has gradually been adopting an apolitical perspective. It seems to me that this is something that has happened to the social professions as a whole due to the new conditions to which the neoliberal approach has subjected them. With a masterful strategy it has provided them with what they most wanted and needed: that which ensures and consolidates their status as 'normal professions'.6 I refer here to the status of scientificity and social recognition, for which they have had to pay a high price.

To work in a 'scientific' way within the framework of neoliberalism, one must evaluate and demonstrate everything one does to external observers, meaning that both the actions and the results must be based on tangible evidence. One must supervise, control, regulate and evaluate everything one does, and not only to be a scientist, but also to be able to demonstrate that the rights of participating people, groups and communities are respected. What matters is not so much the quality of the intervention process and the results produced in the participants, but rather the 'scientific' assurance that it is carried out according to pre-established norms regardless of the characteristics, and even the results, of the social and educational intervention.

Much has been said about the all-devouring capacity of the capitalist system, but the case of the social professions is almost paradigmatic. It has given them what they desired, to be scientific disciplines, and to ensure control has dressed this up as protecting the human rights of the participating people and communities. The terrible thing about this approach is that it eliminates core and essential aspects of the work done by social professionals; a work that is based on closeness in interpersonal relationships.

Important tools of social and educational action are being dismissed due to the prioritising of compliance with bureaucratic and 'scientific' regulations and evidence over the professional's intuition, complicity with the client or participant and expert judgement. How does one evaluate or provide evidence of consolation, accompaniment, human warmth, a reprimand, a caring, stimulating or supportive look in each of the specific cases in which these may be necessary and appropriate? Is there really a need to make such evaluations in all cases and at all times? Does everything have to be evaluated 'scientifically'? I do not mean that evaluation and evidence are not necessary; what I am saying is that putting them first is a poor practice that will generate 'a price that will be paid with the currency usually reserved for the price of bad policy: [with] human suffering' (Bauman, 2015, p. 12).

In the specific case of social pedagogy, following the idea posited by Jacquard (1984) I have pointed out that, as intermediaries, professionals always move within the 'field of betrayals' (Úcar, 2016b, p. 109). Policies, whether administrative, institutional or organisational, mark the limits and possibilities 
of the intervention carried out by socio-educational professionals, who have to deal with this in the specific personal, group or community situation in which they operate. How should we respond to this: implement said policy or, opposing it, follow what the professional code of ethics dictates? (Trappenburg et al., 2019). What, or whom, 'to betray'? Bureaucratic and 'scientific' norms, oneself as a professional or one's clients?

Situations of conflict may arise in which employers perceive professionals' actions as rebellion or abandonment of their professional responsibility, and clients or participants who may perceive it as abandonment or mistrust. Either case can bring into question factors such as professionals' job stability, ethics and credibility, not to mention possible personal emotional conflicts. Extreme positions are clear and do not usually present problems for any of the parties in conflict; situations, for example, where legality and human rights are violated. The problem will not occur in these cases, however, but in those where said legality and rights come into conflict; working, for example, with refugees and, specifically, with unaccompanied minors. This is something that has certainly been very clearly exacerbated within the framework of current neoliberal policies.

\section{Which 'social' are we talking about when we talk about the 'social' in the social professions today?}

One of the first analyses that must be conducted to answer this question is in all likelihood that regarding the relationship between the individual and the social since, as Elias (1990) pointed out, they were differentiated as opposing concepts in the field of politics in the nineteenth century.

It can be said that the individual and the social are clearly intertwined in the societies of the new millennium. They are not two distinct entities but rather a continuum that is difficult to separate, no matter how much the Western tradition of thought has persisted in doing so. The social and the individual are merely the terms we have given ourselves in an attempt to characterise and understand a reality that is otherwise ungraspable due to its complexity. However, today we are aware that they offer only a simplified view of this reality. Following different authors (Dewey, Vigotsky, Suchodolsky, Morin and Wenger, among others) who have analysed this antinomy it is possible to state that the social and the individual are a unique and continuous dimension of what comprises being human, within which it is very difficult, if not impossible, to discern where one begins and the other ends (Úcar, 2016a). Lahire expresses this very well when he points out that 'the collective and the singular are not in any way opposed. They are different and complementary points of view on the same and only social reality' (Lahire, 2013, p. 15).

The manifest mismatch that has emerged in recent decades as a result of increasing complexity between 'the social' and what comprises it has led to numerous authors combining it with the specific dimension they are trying to highlight. One of the most widely used in this respect has been the term 'socio-political', due to its ease of application in the field of social politics.

As previously mentioned, the emergence of culture and cultural policy in the 1970s, and its impact on social pedagogy through socio-cultural animation processes, has also led other authors to employ the term 'socio-cultural'. 'Socio-culture' refers to 'social relations - physical or virtual - generated by the encounter of personal, group and community cultural identities within the framework of a specific cultural or multicultural context' (Úcar, 2016a, p. 16).

The impact of technologies on daily, individual and collective life has also led to the adoption of the term 'social networks', meaning virtual or digital relationships. This is an increasingly essential dimension of life and social relationships and must also therefore be integrated as one of the current dimensions of what we consider to comprise 'the social'.

Another meaning of what we consider 'the social' that has taken centre stage in recent years, or perhaps an alternative concept to it, is that of 'the common' (Laval and Dardot, 2015). This is probably a means, among others, of compensating for the neoliberal approaches that have been established in our societies. Espósito (2007) stated that " the common" always refers to that which begins where "what can be considered one's own" ends' (p. 7). We might say that today 'the social' has become a descriptive term, while 'the common' has normative connotations that make it ideally suited to socio-pedagogical work. Investigating and constructing a social pedagogy as a 'pedagogy of the common' seems to me an idea from and for the future.

Finally, and among many other factors (gender, for example), special emphasis must be placed on the environmental dimension. The concept of 'the social' must necessarily include this dimension if we 
are to survive as a species. Sloterdijk (2018) employed a stark metaphor to express this with great clarity: 'the way human beings treat their planet resembles a catastrophe movie in which rival gangster groups shoot at each other with high-calibre weapons aboard a plane flying at 12,000 metres' (p. 28). Today, what we consider social has to be environmental first and foremost.

It is clear that the current complexity surrounding 'the social' obliges academics and practitioners of social pedagogy and, of the social professions in general, to adapt their understanding of it to the new realities of today. It will be these understandings that end up changing the training and practices of professionals and adapting them to current times. In respect of this, the first task will be to eliminate its accompanying negative connotations: 'the social' refers not only to people, groups and communities in situations of need, vulnerability and risk, but to all people - regardless of their situation.

Benassi (2010) noted that the 1942 Beveridge Report declared universalism to be one of the basic criteria of services the welfare state should provide. In order to eliminate poverty, all citizens must have minimum standards of living for their survival. Instead of following this advice, the then nascent European welfare states, probably subjugated by the economic growth of the time, opted to search for well-being through the market economy. It was not so much about generating what Cortina (1997, p. 72) called 'minimum justice' for all, as about pursuing the 'maximum well-being of society'. As this author pointed out, the former is a concept or state that requires and presupposes negotiation and social consensus, while the latter is an individual and subjective concept that depends on how each individual or state understands well-being. This concept of 'social', focused on those who cannot achieve well-being through the market, has fitted very well with the neoliberal approaches that have taken control of politics in recent decades.

Second, we must think that, as a category of inherently complex actions, the concept of 'the social' subsumes and integrates a whole series of dimensions from the human sphere of action. Today it includes, at the very least, what we consider to be cultural, political, digital and environmental - all dimensions that are fully integrated into the lives of individuals, groups and communities.

The concept of 'the social' is continuous. By no means can it be viewed as discrete and the borders that we have artificially and conventionally erected around it - be they related to disciplines, methodologies or professions - end up being permeated by a reality that surpasses them. For this reason, it would seem essential to establish bridges that connect research and professional experience in the different disciplines and professions that share 'the social' as a sphere of action. The 'social sphere' is too complex to be filled by one single discipline or profession, or to have its constituent parts competing with each other for resources that are scarce. Only through generous interaction by the different professionals and transparent and open dialogue between the different disciplines - education, psychology, sociology, politics, anthropology, pedagogy and social work - will it be possible to provide answers that are at the same time comprehensive, appropriate and suited to the complexity of the social realities that people and communities experience today.

\section{Conclusion: is a better world possible?}

We have stated that social pedagogy is normative, that is, it establishes what must be done (principles, methodologies, norms, techniques, and more) to guide practice. The question is not so much what that practice consists of, however, but where it is headed and what we intend to achieve with it. Or, in other words, which conceptualisation of 'the social' our actions are aimed at: that which we are experiencing today or that which we would like to experience tomorrow. Hence Carballeda's question regarding social work: 'Why does a profession, discipline or method attribute to itself the need for its intervention to transform reality?' (Carballeda, 2002, p. 43). The answer from social pedagogy is clear: because it aspires and works to accompany and help people equip themselves with learning resources that allow them to build lives worth living in the community and environmental frameworks in which they live.

It is not by chance that the concept of 'Buen vivir' (good living) has emerged so forcefully in recent years; initially in indigenous communities and in Latin American thought, but now gradually spreading to different contexts. It is a concept that aims to integrate, among many other dimensions, the social one we have analysed here. A concept that calls into question the neoliberal frameworks in which we still function today; frameworks that have led us to seek the 'buena vida' for a few over the 'vida buena' for all. In the framework of the social professions, it is essential to ask what 'the good life' (Lorenz, 2017, p. 8) is or what it consists of in order to know what to do and how to act. This is a question that the social 
pedagogue and the client must answer together, but also in conjunction with the communities in which they operate.

I have analysed the current meaning of normative in social pedagogy elsewhere, noting that it cannot be understood as a unilateral prescription of the professional, but as something negotiated between both professional and participant within the framework of the socio-educational relationship (Úcar, 2013, 2016b, 2020). The socio-educational relationship is hermeneutic (Lorenz, 2017), which means that within the framework of social pedagogy what comprises 'the social' must be interpreted continuously and jointly between practitioners and clients (Cleary, 2019).

If, however, everything is reduced to the micro-level of the socio-educational relationship, the results of social pedagogy actions and those of all social professions will have a very limited impact. The commitment to 'vida buena' must be made by the planet as a whole; by each individual community, town, society and nation. 'The social' that is proposed as a framework for actions carried out by the social professions is, at the very least, cultural, political, digital and environmental. Prospects for the future clearly point to the fact that it is no longer about living, but about surviving, and that is something that requires the coordinated social (political, cultural, digital and environmental) action of all the communities, societies and countries that make up the planet. One thing appears to be very evident: global situations and problems must be addressed via global actions.

This is not only about addressing situations of inequality and the lack of or an increase in resources, as has traditionally been the case with sociology (Rosa, 2019). Neither are we only focusing on the well-being of people, as the European welfare states did in bypassing (betraying) the universalist sense and direction that the Beveridge Report assigned to these states (Benassi, 2010; Jayasuriya, 2004). It is about making the dignity of people and the commitment to a good life the focal point; combining minimum justice (Cortina, 1997) with the personal axes of resonance (Rosa, 2019) that lead people to have a good life. It seems to me that this is a daring and challenging endeavour social pedagogy and the social professions can undertake. And finally, it is about continuing to pose questions since, as Bauman (2015) stated, 'not asking is the worst response of all' (p. 16).

\section{Notes}

${ }^{1}$ For example, 'the belief that one had to learn something suitable so as to have an easier later life, an idea dictated by a petit bourgeois trust in schooling. However, this trust is disintegrating today' (Sloterdijk, 2014, p. 16).

${ }^{2}$ Although he initially refers to teachers, doctors and priests, in his research he includes a good part of the so-called social professions, given that they are professions dedicated to working on others (Dubet, 2006).

${ }^{3}$ Man is naturally political, that is, social.

${ }^{4}$ Theoretically and historically, social pedagogy has been oriented towards: (a) resolving social problems, and/or, (b) democratisation and improving social and cultural life (Rothuizen and Harbo, 2017).

${ }^{5}$ Collective reflection on culture as an element of how peoples develop began in Europe after the Second World War within the framework of the newly created supra-state institutions: the Council of Europe and the Council for Cultural Cooperation. The first world conference on culture was held in Venice in 1970, resulting in cultural policy being included on governments' agendas.

${ }^{6}$ The long and winding road for many of today's social professions to acquire socially recognised professional status is well-known. They have been previously characterised as 'occupations' or 'semi-professions' (Banks, 1999; Blom et al., 2017; Healy, 2009; Sáez and Sánchez, 2006).

7The good life in the sense of 'vida buena' is 'the result of a relationship with the world that is characterised by establishing and maintaining stable "axes of resonance", which allow subjects to feel "sustained and borne" and even "protected" in a responsive and friendly world" (Rosa, 2019, p. 49). In Spanish, 'buena vida' has connotations related to a selfish enjoyment of life not subject to the rules of coexistence.

\section{Declarations and conflict of interests}

The author declares no conflicts of interest with this work. 


\section{References}

Arendt, H. (2002). La condición humana. Barcelona: Paidós.

Banks, S. (1999). The social professions and social policy: Proactive or reactive? European Journal of Social Work, 2(3), 327-39. [CrossRef]

Banks, S. (2004). Ethics, accountability and the social professions. Basingstoke: Palgrave Macmillan.

Bauman, Z. (2015). En busca de la política. Mexico City: Fondo de Cultura Económica.

Benassi, D. (2010). 'Father of the welfare state'? Beveridge and the emergence of the welfare state. Sociologica, 3, 1-21. [CrossRef]

Blom, B., Evertsson, L., \& Perlinski, M. (2017). Social and caring professions in European welfare states: Policies, services and professionals' practices. Bristol: Policy Press.

Bregman, R. (2017). Utopía para realistas. A favor de la renta básica universal, la semana laboral de 15 horas y un mundo sin fronteras. Barcelona: Ediciones Salamandra.

Bruhn, A. (2019). Social and caring professions in European welfare states. Policies, services and professional practices. Nordic Social Work Research, 9(2), 199-201. [CrossRef]

Carballeda, A. J. (2002). La intervención en lo social. Exclusión e integración en los nuevos escenarios sociales. Buenos Aires: Paidos SAICF.

Caride, J. A. (2004). ¿Qué añade lo 'Social' al sustantivo 'Pedagogía'? Pedagogía Social. Revista interuniversitaria. Segunda época, 11, 55-85.

Carreira da Silva, F. (2017). Welfare state. In W. Outhwaite \& S. Turner (Eds.), The SAGE handbook of political sociology (pp. 944-57). London: SAGE Publications.

Cleary, B. (2019). Reinterpreting bildung in social pedagogy. International Journal of Social Pedagogy, 8(1), 3. [CrossRef]

Cortina, A. (1997). Ciudadanos del mundo. Hacia una teoría de la ciudadanía. Madrid: Alianza Editorial.

Coussée, F., Bradt, L., Roose, R., \& Bouverne-De Bie, M. (2010). The emerging social, pedagogical paradigm in UK child and youth care: Deus ex machina or walking the beaten path. British Journal of Social Work, 40, 789-805.

Curtis, B. (2002). Surveying the social: Techniques, practices, power. Histoire Sociale/Social History, 35(69), 83-108.

Dubet, F. (2006). El declive de la institución. Profesiones, sujetos e individuos en la modernidad. Barcelona: Gedisa.

Dubet, F. (2013). El trabajo de las sociedades. Buenos Aires: Amorrurtu Editores.

Dundar Aravacik, E. (2018). Social policy and the welfare state. Public Economics and Finance. Accessed 14 July 2021. https://www.intechopen.com/books/public-economics-and-finance/socialpolicy-and-the-welfare-state.

Elias, N. (1990). La sociedad de los individuos. Barcelona: Península.

Eriksson, L., \& Markström, A. M. (2003). Interpreting the concept of social pedagogy. In A. Gustavsson, H. Hermanson \& J. Hämäläinen (Eds.), Perspectives and theory in social pedagogy (pp. 9-22). Gothenburg: Bokförlaget Daidalos A.B.

Espósito, R. (2007). Communitas: origen y destino de la comunidad. Buenos Aires: Amorrurtu.

Feldman, G. (2019). Making the connection between theories of policy change and policy practice: A new conceptualization. British Journal of Social Work, 50(4), 1089-106. [CrossRef]

Ferrera, M. (2008). The European welfare state: Golden achievements, silver prospects. West European Politics, 3(11-12), 82-107. [CrossRef]

García Roca, J. (2004). Políticas y programas de participación social. Madrid: Síntesis.

Goul Andersen, J. (2012). Welfare states and welfare state theory. Accessed 14 July 2021. https://vbn. aau. dk/ws/portalfiles/portal/72613349/80_2012_J_rgen_Goul_Andersen.pdf.

Graham, M. (2011). Changing paradigms and conditions of childhood: Implications for the social professions and social work. British Journal of Social Work, 41, 1532-47. [CrossRef]

Green, L., \& Clarke, K. (2016). Social policy for social work. Cambridge: Polity.

Hämäläinen, J. (2003a). The concept of social pedagogy in the field of social work. Journal of Social Work, 3, 69-80.

Hämäläinen, J. (2003b). Developing social pedagogy as an academic discipline. In A. Gustavsson, H. Hermansson \& J. Hämäläinen (Eds.), Perspectives and theory in social pedagogy (pp. 133-53). Gothenburg: Bokförlaget Daidalos A.B.

Hämäläinen, J. (2012). Social pedagogical eyes in the midst of diverse understandings, conceptualizations and activities. International Journal of Social Pedagogy, 1(1), 3-16. 
Hamlin, A. (2007). The idea of welfare and the welfare state. Symposium on 'welfare in the 21st century' for the Journal Public Finance and Management. Accessed 14 July 2021. http://hummedia.manchester. ac.uk/schools/soss/politics/research/workingpapers/mancept/ldeaofWELFARE2.pdf.

Hartman, Y. (2005). In bed with the enemy: Some ideas on the connections between neoliberalism and the welfare state. Current Sociology, 53(1), 57-73. [CrossRef]

Healy, K. (2009). A case of mistaken identity: The social welfare professions and new public management. Journal of Sociology, 45(4), 401-18. [CrossRef]

Honneth, A. (2011). La sociedad del desprecio. Madrid: Trotta.

Jacquard, A. (1984). Inventer l'homme. Paris: Éditions Complexe.

Janer, A., \& Úcar, X. (2019a). An international comparison: Social pedagogy training. Journal of Social Work, 19(2), 253-75. [CrossRef]

Janer, A., \& Úcar, X. (2019b). Social pedagogy in the world today: An analysis of the academic, training and professional perspectives. The British Journal of Social Work, 50(3), 702-21.

Jayasuriya, J. (2004). The new regulatory state and relational capacity. Policy Politics, 32(4), 487-501.

Kornbeck, J. (2009). 'Important but widely misunderstood': The problem of defining social pedagogy in Europe. In J. Kornbeck \& N. Rosendal Jensen (Eds.), The diversity of social pedagogy in Europe. Studies in Comparative Social Pedagogies and International Social Work and Social Policy (pp. 211-36). Bremen: Bremen: EHV GmbH \& Co. KG.

Kornbeck, J. (2013). Transatlantic issues in social pedagogy: What the United Kingdom can learn from Iberoamerica. Scottish Journal of Residential Child Care, 12(1), 58-75.

Kraav, I. (2003). Development perspectives of social pedagogy in Estonia. In A. Gustavsson, H. Hermanson \& J. Hämäläinen (Eds.), Perspectives and theory in social pedagogy (pp. 117-33). Gothenburg: Bokförlaget Daidalos A.B.

Lahire, B. (2013). Dans les plis singuliers du social: Individus, institutions, socialisations. Paris: La Découverte.

Laval, C. H., \& Dardot, P. (2015). ComÚn. Ensayo sobre la revolución en el siglo XXI. Barcelona: Gedisa.

Lorenz, W. (2008). Paradigms and politics: Understanding methods paradigms in an historical context: The case of social pedagogy. British Journal of Social Work, 38(4), 625-44. [CrossRef]

Lorenz, W. (2017). Social work education in Europe: Towards 2025. European Journal of Social Work, 20(3), 311-21. [CrossRef]

Lorenzova, J. (2017). Childhood through the lens of social pedagogy. International Journal of Social Sciences, 6(1), 53-70. [CrossRef]

Manuel, J. T. (2010). Rethinking the social in social studies. The Councilor: The Journal of the Illinois Council for the Social Studies, 71(2), 1-11.

Mendoza, X., \& Vernis, A. (2008). The changing role of governments and the emergence of the relational state. Corporate Governance, 8(4), 389-96. [CrossRef]

Muñoz de Bustillo Llorente, R. (2019). Key challenges for the European welfare states. (JRC117351), Joint Research Centre. Seville: European Commission.

Petrie, P., \& Cameron, C. (2009). Importing social pedagogy. In J. Kornbeck \& N. Rosendal Jensen (Eds.), The diversity of social pedagogy in Europe (pp. 145-69). Bremen: EHV GmbH \& Co. KG.

Rendueles, C. (2013). Sociofobia. El cambio político en la era de la utopía digital. Madrid: Capitán Swing.

Rosa, H. (2019). Resonancia. Una sociología de la relación con el mundo. Madrid: Katz Editores.

Rosanvallon, P. (1995). La crisis del Estado del Bienestar. Madrid: Cívitas.

Rothuizen, J. J., \& Harbo, L. J. (2017). Social pedagogy: An approach without fixed recipes. International Journal of Social Pedagogy, 6(1), 6-28. [CrossRef]

Sáez, J., \& Sánchez, M. (2006). Trust and professionalism in social professions: The case of social education. Current Sociology, 54(4), 595-606.

Schugurensky, D., \& Silver, M. (2013). Social pedagogy: Historical traditions and transnational connections. Education Policy Analysis Archives (special issue), 21(35), 21. [CrossRef]

Sloterdijk, P. (2014). Los hijos terribles de la edad moderna. Sobre el experimento genealógico de la modernidad. Madrid: Siruela.

Sloterdijk, P. (2016). Experimentos con uno mismo. Una conversación con Carlos Oliveira. Valencia: Pre-textos.

Sloterdijk, P. (2018). ¿Qué sucedió en el siglo XX? Madrid: Siruela.

Smirnova, A., \& Poluektova, N. (2019). Professionalization of social work in Russia: Challenges for education system. Social Work Education, 38(3), 347-58. [CrossRef]

Smith, M., \& Whyte, B. (2007). Social education and social pedagogy: Reclaiming a Scottish tradition in social work. European Journal of Social Work, 11(1), 15-28. [CrossRef] 
Storø, J. (2013). Practical social pedagogy: Theories, values and tools for working with children and young people. Bristol: Policy Press.

Swedberg, R. (2016). El arte de la teoría social. Madrid: Centro de Investigaciones Sociológicas.

Touraine, A. (2013). La fin des sociétés. Paris: Éditions du Seuil.

Trappenburg, M., Kampen, T., \& Tonkens, E. (2019). Social workers in a modernising welfare state: Professionals or street-level bureaucrats? The British Journal of Social Work, 50(6), 1669-87. [CrossRef]

Úcar, X. (2011). Social pedagogy: Beyond disciplinary traditions and cultural contexts? In J. Kornbeck \& N. Rosendal Jensen (Eds.), Social pedagogy for the entire human lifespan (pp. 125-56). Bremen: EHV GmbH \& Co. KG.

Úcar, X. (2013). Exploring different perspectives of social pedagogy: Towards a complex and integrated approach. Education Policy Analysis Archives, 21(36), 1-19.

Úcar, X. (2016a). Pedagogías de lo social. Barcelona: UOC.

Úcar, X. (2016b). Relaciones socioeducativas. La acción de los profesionales. Barcelona: UOC.

Úcar, X. (2020). Social pedagogy and socio-educational work with young people. In X. Úcar, P. Soler-Masò \& A. Planas-Lladò (Eds.), Working with young people: A social pedagogy perspective from Europe and Latin America (pp. 13-32). New York: Oxford University Press.

UNESCO. (1997). Nuestra diversidad creativa: informe de la Comisión Mundial de Cultura y Desarrollo. Madrid: Ediciones UNESCO/Fundación Santa María. 